\title{
FAKTOR - FAKTOR YANG BERHUBUNGAN DENGAN KEJADIAN PNEUMONIA PADA BALITA DI RSUD LEWOLEBA
}

\author{
Iser Leonardus ${ }^{1}$, Lina Dewi Anggraeni ${ }^{2}$ \\ STIKES Sint Carolus Program Studi S1 Keperawatan
}

\begin{abstract}
Background: Pneumonia is an inflammation occurs in the lung parenchymal tissue. Profil Kesehatan Provinsi Nusa Tenggara Timur at 2015 show the scope of the discovery and the handling of pneumonia in toddlers at 3.757 (reached $6.03 \%$ ) and based on district, kabupaten lembata was ranked to 4 with $12 \%$ of cases. The purpose of this research is to know about determine of factors that associated with the incidence of pneumonia in children under-five years old at the Lewoleba hospital. Method: quantitative method with descriptive correlative research design and cross sectional approach, sample in research 65 with totality sampling. Result: showed that correlation between parent education level ( $p$ value $=0,000)$, nutritional status of children under five years old ( $p$ value $=0,000)$, history of low birth weight ( $p$ value $=$ $0,000)$, presence of family member of smokers ( $p$ value $=0,000)$, use of cooking fuel ( $p$ value $=0,000)$, and knowledge of parents ( $p$ value $=0,000)$ with pneumonia incidence in under-five children. Conclusion: Health workers expected can give health promotion such as prevention to parental of children under-five years old.
\end{abstract}

Keywords: Pneumonia; Under-five years old; nutritional status

\section{PENDAHULUAN}

Balita adalah anak yang sudah menginjak umur satu tahun dengan rentang umur 1 sampai 5 tahun (Kemenkes RI, 2014). Anak balita dikelompokan menjadi todller yaitu balita umur 1 - 3 tahun dan preschool 3 sampai 5 tahun (Hockenberry \& Wilson, 2016). Jumlah balita di Indonesia menurut Profil Kesehatan Indonesia (2016) yaitu 22.960.310 jiwa. Masa ini balita sering juga disebut sebagai fase "Golden Age" yang merupakan masa yang sangat penting untuk memperhatikan tumbuh kembang maupun pada balita secara cermat agar sedini mungkin dapat terdeteksi apabila terjadi kelainan atau pun penyakit (Chamidah, 2009).

Balita dikelompokan sebagai usia anak yang mudah terserang penyakit
(Infodatin Anak, 2015). Penyakit yang biasanya menyerang balita dan menyebabkan kematian antara lain diare yang menempati urutan pertama $(25,2 \%)$, enterokolitis $(10,7 \%)$, meningitis $(8,8$ $\%)$, DBD (6,8\%), campak (5,8 \%), tenggelam $(4,9 \%)$, TB $(3,9 \%)$ malaria $(2,9 \%)$, leukemia $(2,9 \%)$, lain - lain (12, $\%)$, dan pneumonia yang menempati urutan kedua dengan presentasi $(15,5 \%)$ (Kemenkes RI, 2010).

Menurut Hockenberry dan Wilson (2015) pneumonia adalah penyakit peradangan pada parenkim paru - paru. Pneumonia adalah infeksi dan inflamasi pada terminal airways dan alveolus (Huether \& McCance, 2017). Hockenberry dan Wilson (2015) mengatakan bahwa pneumonia pada balita umumnya disebabkan oleh 
$\begin{array}{lrr}\text { mikroorganisme } & \text { seperti } & \text { RSV } \\ \text { (Respiratory } \quad \text { Syncytial } & \text { Virus), } \\ \text { parainfluenza, influenza, } & \text { human } \\ \text { metapneumovirues, } & \text { adenoviruses, } \\ \text { mycoplasma pneumonia, dan } S .\end{array}$

Pneumonia. Menurut Kliegman (2016) selain mikroorganisme, penyebab non infeksius pneumonia antara lain aspirasi asam lambung, gas hidrokarbon, dan reaksi hipersesitifitas. Hockenberry dan Wilson (2015) mengungkapkan tanda dan gejala klinis pada balita yang menderita pneumonia adalah demam tinggi mencapai suhu $39-41^{\circ} \mathrm{C}$ (Fleisher \& Ludwig, 2010), napas cepat, mengigil, kaku, batuk produktif atau adanya sekret atau dahak

\section{Menurut World Health}

Organization/WHO (2013), Pneumonia menjadi penyebab utama kematian pada anak balita di seluruh dunia dengan jumlah sekitar 1,6 juta kematian per tahun. Lebih dari 99\% kematian pneumonia terjadi di negara berpenghasilan rendah dan menengah. Asia Selatan dan Afrika sub-Sahara memiliki lebih dari separuh jumlah kasus pneumonia di kalangan balita di seluruh dunia.. Menurut WHO (2014) angka kematian anak akibat pneumonia di seluruh dunia sebanyak 935.000 anak pada tahun 2013.

Tahun 2013 angka cakupan penemuan pneumonia balita yaitu berkisar antara 23\%-27\% dengan angka kematian sebesar 1,19\% (Profil Kesehatan Indonesia, 2013). Period prevalence dan prevalensi tahun 2013 untuk kasus pneumonia di Indonesia sebesar 1,8 persen dan 4,5 persen, Lima provinsi yang mempunyai insiden dan prevalensi pneumonia tertinggi untuk semua umur adalah Nusa Tenggara Timur $(4,6 \%$ dan $10,3 \%)$, Papua $(2,6 \%$ dan
8,2\%), Sulawesi Tengah (2,3\% dan $5,7 \%)$, Sulawesi Barat $(3,1 \%$ dan $6,1 \%)$, dan Sulawesi Selatan (2,4\% dan 4,8\%) (Riskesdas, 2013). Proporsi penemuan pneumonia pada balita di Indonesia sebesar $>20 \%$ dari semua kasus pneumonia. Period prevalence pneumonia pada balita di Indonesia adalah 18,5 per mil, balita dengan pneumonia yang berobat hanya 1,6 per mil. Lima provinsi yang mempunyai insiden pneumonia balita tertinggi adalah Nusa Tenggara Timur $(38,5 \%)$, Aceh (35,6\%), Bangka Belitung (34,8\%), Sulawesi Barat $(34,8 \%)$, dan Kalimantan Tengah (32,7\%), insiden tertinggi pneumonia balita terdapat pada kelompok umur 12-23 bulan (Riskesdas, 2013).

Tahun 2014 angka cakupan penemuan pneumonia pada balita tidak mengalami perkembangan berarti yaitu berkisar antara 20\% - 30\%, namun pada tahun 2015 terjadi peningkatan menjadi 63,45\% (Profil Kesehatan Indonesia, 2015). Salah satu penyebab peningkatan penemuan yaitu sasaran penemuan pneumonia yang sebelumnya sama untuk semua provinsi (10\%), pada tahun 2015 menggunakan hasil Riskesdas 2013 yang berbeda-beda untuk setiap provinsi dan secara nasional sebesar 3,55\% (Profil Kesehatan Indonesia, 2015). Tahun 2016, jumlah kasus pneumonia di Indonesia sebesar 503.738 kasus dengan presentasi $57,84 \%$, namun beberapa propinsi yang belum memiliki data pneumonia pada balita antara lain DI Yogyakarta, Nusa Tenggara Timur, Papua barat dan Papua (Profil Kesehatan Indonesia, 2016).

Menurut Profil Kesehatan Indonesia (2013) angka kematian akibat pneumonia sebesar 1.19\%, pada kelompok bayi angka kematian lebih besar yaitu $2.89 \%$ dari pada kelompok 1 - 
4 yang sebesar $0.20 \%$. Angka kematian akibat pneumonia pada balita tahun 2015 sebesar $0,16 \%$, lebih tinggi dibandingkan dengan tahun 2014 yang sebesar 0,08\% (Profil Kesehatan Indonesia, 2015). Pneumonia juga selalu berada pada daftar 10 penyakit terbesar setiap tahunnya di setiap fasilitas. Hal ini menunjukan pneumonia merupakan penyakit yang masih menjadi masalah kesehatan utama dan berkontribusi pada tingginya angka kematian balita di Indonesia (Kemenkes RI, 2013).

Profil Kesehatan Provinsi NTT (2015) menunjukkan cakupan penemuan dan penanganan Pneumonia pada Balita tahun 2015 yaitu sebesar 3.757 (6,03\%). Berdasarkan kota/kabupaten, kabupaten Lembata berada pada urutan ke 4 dengan 12\% kasus (Profil Kesehatan NTT, 2015). Data pneumonia di Rumah Sakit Umum Lewoleba Kabupaten Lembata tahun 2016 ditemukan 28 kasus pada balita laki - laki dan 35 kasus pada balita perempuan. Penemuan kasus pneumonia dari Januari sampai Juni 2017 antara lain laki - laki 13 kasus dan perempuan 12 kasus.

Tingginya angka kejadian pneumonia ini disebabkan beberapa faktor resiko antara lain umur kurang dari dua tahun, kepadatan penduduk, musim dingin, resintesi antibiotik, daycare attendance, paparan asap rokok, status nutrisi, dan pengaruh penyakit penyerta (Huether \& McCance, 2017). Menurut Kemenkes (2011) Environmental Tobacco Smoke (ETS) salah satunya menyebabkan gangguan pernapasan seperti pneumonia pada balita.

Menurut Kemenkes (2011) salah satu sumber dari pencemaran udara dalam rumah yaitu penggunaan energi biomasa dari bahan bakar kayu dan batu bara untuk memasak dari pada penggunaan LPG dan minyak tanah. kualitas udara yang rendah menyebabkan berbagai masalah kesehatan seperti infeksi pernapasan seperti pneumonia.

Selain data - data kejadian pneumonia maupun penelitian terkait di atas, menurut pengamatan peneliti tempat penelitian di Lewoleba rumah - rumah penduduk banyak yang kurang memiliki ventilasi yang memadai, penggunaan kayu bakar untuk memasak, kemudian perilaku merokok dalam keluarga. Hal ini menjadi alasan peneliti tertarik melakukan penelitian terkait faktor faktor yang berhubungan dengan kejadian pneumonia pada balita di Rumah Sakit Umum Daerah Lewoleba kabupaten Lembata tahun 2018.

\section{METODE PENELITIAN}

Jenis penelitian yang dilakukan dalam penelitian ini adalah bersifat analitik yang bertujuan untuk mengetahui faktor - faktor yang berhubungan dengan kejadian pneumonia pada balita di Rumah Sakit Umum Daerah Lewoleba kabupaten Lembata tahun 2018. Rancangan

penelitian yang dilakukan dalam penelitian ini dengan desain penelitian cross sectional dimana variabel independen dan dependen diteliti secara langsung dalam waktu bersamaan. Lokasi penelitian Rumah Sakit Umum Daerah Lewoleba, Lembata, Nusa Tenggara Timur. Alasan pemilihan lokasi ini karena cakupan penemuan dan penanganan Pneumonia pada balita yaitu sebesar $3.757 \quad(6,03 \%)$ dan berdasarkan kota/kabupaten, kabupaten Lembata berada pada urutan ke 4 dengan 12\% kasus. Pemilihan sampel dilakukan dengan menggunakan teknik pengambilan sampel secara total sampling. Populasi 
anak balita di RSUD Lewoleba yaitu 65 orang. Sampel yang digunakan dalam penelitian ini adalah orang tua yang memiliki pasien anak balita yang dirawat inap di RSUD Lewoleba pada bulan Februari 2018 sampai Mei 2018.

\section{HASIL DAN PEMBAHASAN}

\section{ANALISA UNIVARIAT}

Tabel 1. Distribusi frekuensi karakteristik responden

\begin{tabular}{|c|c|c|}
\hline Variabel & Jumlah & Presentase \\
\hline \multicolumn{3}{|c|}{ Umur balita } \\
\hline $\begin{array}{l}1 \text { sampai } \\
<3 \text { tahun }\end{array}$ & 40 & 61,5 \\
\hline $\begin{array}{l}\geq 3 \\
\text { sampai } 5 \\
\text { tahun }\end{array}$ & 25 & 38,5 \\
\hline \multicolumn{3}{|c|}{ Jenis Kelamin } \\
\hline Laki-laki & 33 & 50,8 \\
\hline Perempuan & 32 & 49,2 \\
\hline \multicolumn{3}{|c|}{ Pendidikan Orang tua } \\
\hline Tinggi & 32 & 49,2 \\
\hline Rendah & 33 & 50,8 \\
\hline \multicolumn{3}{|l|}{ Status Gizi } \\
\hline Buruk & 14 & 21,5 \\
\hline Sedang & 17 & 26,2 \\
\hline Baik & 34 & 52,3 \\
\hline \multicolumn{3}{|c|}{ Riwayat BBLR } \\
\hline $\begin{array}{l}\text { Tidak ada } \\
\text { data }\end{array}$ & 50 & 76,9 \\
\hline Ada & 15 & 23,1 \\
\hline \multicolumn{3}{|c|}{ Status Imunisasi } \\
\hline $\begin{array}{l}\text { Tidak } \\
\text { Lengkap }\end{array}$ & 12 & 18,5 \\
\hline Lengkap & 53 & 81,5 \\
\hline \multicolumn{3}{|c|}{ Anggota Keluarga Perokok } \\
\hline $\begin{array}{l}\text { Tidak } \\
\text { Ada }\end{array}$ & 27 & 42,5 \\
\hline Ada & 38 & 58,5 \\
\hline \multicolumn{3}{|c|}{ Bahan Bakar Masak } \\
\hline $\begin{array}{l}\text { Kayu } \\
\text { bakar }\end{array}$ & 28 & 43,1 \\
\hline $\begin{array}{l}\text { LPG dan } \\
\text { minyak }\end{array}$ & 37 & 56,9 \\
\hline
\end{tabular}

tanah

\section{Pengetahun orang tua}

\begin{tabular}{|c|c|c|}
\hline Kurang & 17 & 26,2 \\
\hline Cukup & 22 & 33 \\
\hline Baik & 26 & \\
\hline \multicolumn{3}{|c|}{ Kejadian Pnemonia } \\
\hline Pnemonia & 32 & \\
\hline Tidak & 34 & \\
\hline
\end{tabular}

Penelitian ini menggunakan kategori golongan umur balita menurut Hockenberry dan Wilson (2016) yaitu Anak balita dikelompokan menjadi toddler yaitu balita umur $1-3$ tahun dan preschool 3 sampai 5 tahun. Berdasarkan tabel 1, dari 65 responden yang diteliti mayoritas memiliki balita yang berumur 1 sampai kurang dari 3 tahun yaitu sebanyak $61,5 \%$. Berdasarkan konsep epidemiologi penyakit, umur menjadi salah satu indikator faktor resiko terhadap suatu penyakit. Menurut Huether dan McCance (2017) salah satu faktor resiko pneumonia pada balita yaitu balita dengan umur kurang dari 2 tahun. Hal ini sesuai dengan tabel distribusi frekuensi di atas bahwa balita dengan umur 1 sampai kurang dari 3 tahun lebih banyak dirawat di RSUD Lewoleba.

Tingkat pendidikan dibagi menjadi pendidikan rendah yaitu tidak sekolah, SD, SMP dan sederajat, sedangkan pendidikan tinggi yaitu SMA dan sederajat, Diploma atau perguruan tinggi (Arikunto, 2006 dalam Wawan dan Dewi, 2011). Berdasarkan tabel 1 distribusi frekuensi tingkat pendidikan orang tua balita yang dirawat di RSUD Lewoleba, lebih banyak orang tua yang memiliki tingkat pendidikan tinggi yaitu sebesar 50,8\%. Hal ini sejalan dengan angka partisipasi sekolah (APS) kabupaten Lembata tahun 2015 yang 
mencapai 97,34\% (Bappenas, 2015), sehingga sudah banyak orang tua yang memiliki pendidikan tinggi.

Status gizi balita yang dirawat di RSUD Lewoleba lebih banyak memiliki status gizi baik yaitu sebesar 52,3\% . Status gizi anak balita di NTT khususnya kabupaten Lembata sudah lebih baik berdasarkan tabel di atas hal ini karena adanya upaya dari Propinsi NTT maupun Kabupaten Lembata untuk perbaikan gizi antara lain (Dinas Kesehatan NTT, 2016): pemantauan pertumbuhan balita, pemberian tablet vitamin A, dan pemberian tablet besi (Fe). Hal ini dilakukan melalui kegiatan pos pelayanan terpadu (POSYANDU).

Balita yang dirawat di RSUD lebih banyak tidak memiliki riwayat BBLR yaitu sebesar 76,9\%. Hal ini karena adanya program pelayanan Antenatal (K1 dan K4) oleh pemerintah kabupaten Lembata yaitu akses pelayanan ibu hamil terhadap pelayanan kesehatan untuk mendapat pelayanan antenatal (Dinas Kesehatan NTT, 2016). Pelayanan antenatal salah satunya bertujuan untuk mencegah kelahiran berat rendah pada bayi (BBLR) (Anggraeny \& Ariestiningsih, 2017).

Balita yang dirawat di RSUD lewoleba lebih banyak memiliki status imunisasi lengkap yaitu sebesar 81,5\% . Adanya program pemerintah kabupaten lembata yaitu Universal Child Imunization (UCI) yang mencapai 80\% (Dinas Kesehatan Provinsi NTT, 2016) sehingga banyak balita di Kabupaten Lembata yang sudah memiliki status imunisasi yang lengkap.

Balita yang dirawat di RSUD Lewoleba yang memiliki keluarga perokok lebih banyak yaitu sebesar $58,5 \%$. Menurut penelitian yang dilakukan oleh Putra dan Astrini (2014) mengenai hubungan karakteristik dan tingkat pengetahuan terhadap perilaku merokok, salah satu hasilnya yaitu ada hubungan antara pendapatan dengan kebiasaan merokok, oleh karena berdasarkan tabel di atas kebanyakan orang tua balita memiliki penghasilan sehingga memiliki kebiasaan merokok.

Bahan bakar masak lebih banyak yang digunakan di rumah oleh orang tua balita yang dirawat di RSUD lewoleba yaitu LPG dan minyak tanah yaitu sebesar 56,9\%. Berdasarkan pengamatan peneliti, masyarakat kota Lewoleba, ibukota kabupaten Lembata sudah lebih maju perekonomiannya, sehingga sudah banyak masyarakat yang menggunakan LPG dan minyak tanah sebagai bahan bakar masak.

Pengetahuan orang tua balita yang dirawat di RSUD Lewoleba lebih banyak memiliki pengetahuan yang baik yaitu sebesar $40,0 \%$. Berdasarkan tabel 5.3 distribusi frekuensi pendidikan orang yang memiliki balita yang dirawat di RSUD Lewoleba lebih banyak orang tua memiliki pendidikan yang tinggi yaitu $50,8 \%$ sehingga lebih banyak orang tua memiliki tingkat pengetahuan yang baik.

\section{PEMBAHASAN}

Tabel 2. Analisis Bivariat Faktor - faktor yang berhubungan dengan kejadian pneumonia pada balita di RSUD Lewoleba 


\begin{tabular}{|c|c|c|c|c|c|}
\hline \multirow[t]{3}{*}{ Variabel } & \multicolumn{4}{|c|}{ Kejadian Pnemonia } & \multirow{3}{*}{$\begin{array}{l}\mathbf{P} \\
\text { value }\end{array}$} \\
\hline & \multicolumn{2}{|c|}{ Pnemonia } & \multicolumn{2}{|c|}{$\begin{array}{c}\text { Tidak } \\
\text { Pnemonia }\end{array}$} & \\
\hline & $\mathbf{N}$ & $\%$ & $\mathbf{N}$ & $\%$ & \\
\hline \multicolumn{6}{|c|}{ Umur balita } \\
\hline 1 sampai & 21 & 52,5 & 19 & 47,5 & \multirow{3}{*}{0,326} \\
\hline$<3$ tahun & & & & & \\
\hline $\begin{array}{c}\geq 3 \\
\substack{\text { sampai } 5 \\
\text { tahun }}\end{array}$ & 10 & 40 & 15 & 60 & \\
\hline \multicolumn{6}{|c|}{ Jenis Kelamin } \\
\hline Laki-laki & 15 & 45,5 & 18 & 54,5 & \multirow{2}{*}{0,714} \\
\hline Perempuan & 16 & 50 & 16 & 50,0 & \\
\hline \multicolumn{6}{|c|}{ Pendidikan Orang tua } \\
\hline Tinggi & 23 & 71,9 & 9 & 28,1 & \multirow{2}{*}{0,000} \\
\hline Rendah & 8 & 24,2 & 25 & 75,8 & \\
\hline \multicolumn{6}{|l|}{ Status Gizi } \\
\hline Buruk & 14 & 100 & 0 & 0,00 & \multirow{3}{*}{0,000} \\
\hline Sedang & 12 & 70,4 & 5 & 29,6 & \\
\hline Baik & 5 & 14,7 & 29 & 85,3 & \\
\hline \multicolumn{6}{|c|}{ Riwayat BBLR } \\
\hline $\begin{array}{l}\text { Tidak ada } \\
\text { data }\end{array}$ & 17 & 34,0 & 33 & 66,0 & \multirow{2}{*}{0,000} \\
\hline Ada & 14 & 93,3 & 1 & 6,7 & \\
\hline \multicolumn{6}{|c|}{ Status Imunisasi } \\
\hline Tidak & 8 & 66,7 & 4 & 33,3 & \multirow{3}{*}{0,145} \\
\hline Lengkap & & & & & \\
\hline Lengkap & 23 & 43,4 & 30 & 56,6 & \\
\hline \multicolumn{6}{|c|}{ Anggota Keluarga Perokok } \\
\hline Tidak & 0 & 0,00 & 27 & 100 & \multirow{3}{*}{0,000} \\
\hline Ada & & & & & \\
\hline Ada & 31 & 81,6 & 7 & 18,3 & \\
\hline \multicolumn{6}{|c|}{ Bahan Bakar Masak } \\
\hline $\begin{array}{l}\text { Kayu } \\
\text { bakar }\end{array}$ & 27 & 96,4 & 1 & 3,6 & \multirow[t]{2}{*}{0,000} \\
\hline $\begin{array}{l}\text { LPG } \\
\text { dan } \\
\text { minyak } \\
\text { tanah }\end{array}$ & 7 & 18,9 & 30 & 81,1 & \\
\hline \multicolumn{6}{|c|}{ Pengetahun orang tua } \\
\hline Kurang & 16 & 94,1 & 1 & 5,9 & \multirow{3}{*}{0,000} \\
\hline Cukup & 7 & 31,8 & 15 & 68,2 & \\
\hline Baik & 8 & 30,0 & 18 & 69,2 & \\
\hline
\end{tabular}

Hubungan antara umur balita dengan kejadian pneumonia pada balita yang dirawat di RSUD Lewoleba

Berdasarkan tabel 2 ditemukan bahwa proporsi kejadian pneumonia pada balita lebih banyak terjadi pada balita yang berumur 1 sampai kurang dari 3 tahun sebanyak 21 balita dengan presentase $52,5 \%$ sedangkan kejadian pneumonia pada balita yang berumur kurang dari sama dengan 3 sampai 5 tahun sebanyak 10 balita dengan presentase $40 \%$. Dari hasil uji chi square didapatkan nilai $p$ value sebesar 0,326 atau $\mathrm{P}>0,05$ yang berarti secara statistik tidak ada hubungan antara umur balita dengan kejadian pneumonia pada balita di RSUD Lewoleba.

Hasil penelitian ini sejalan dengan penelitian yang dilakukan oleh Oktaviani dan Maesaroh (2017) dalam penelitiannya yang berjudul Faktor - Faktor Yang Berhubungan Dengan Kejadian Pneumonia Pada Balita Di Puskesmas Kecamatan Teluknaga Kabupaten Tangerang. Hasil penelitiannya menunjukan tidak ada hubungan antara umur dengan kejadian pneumonia pada balita dengan hasil uji statistik $\mathrm{p}=0,572$ atau $\mathrm{p}>0,05$.

Penelitian ini menggunakan kategori golongan usia balita menurut Hockenberry dan Wilson (2016) yaitu Anak balita dikelompokan menjadi toddler yaitu balita umur $1-3$ tahun dan preschool 3 sampai 5 tahun. Sesuai dengan penelitian yang dilakukan oleh Kaunang, Runtunuwu, dan Mahawani (2016) bahwa kelompok usia yangmudah dan lebih banyak mengalami pneumonia yaitu kelompok kelompok usia bayi atau kelompok usia < 1 tahun diikuti kelompok usia dini 1 sampai 3 tahun dan usia prasekolah 3 sampai 6 tahun. 
Menurut asumsi peneliti, umur menjadi salah satu indikator faktor resiko terhadap suatu penyakit termasuk pneumonia pada balita. Semakin rendah umur balita semakin beresiko terkena pneumonia karena terkait kematangan orang tubuh yang secara langsung berhubungan dengan pertahanan tubuh terhadap penyakit termasuk pneumonia.

\section{Hubungan antara jenis kelamin balita dengan kejadian pneumonia pada balita di RSUD Lewoleba}

Berdasarkan tabel 2 kejadian pneumonia pada balita yang berjenis kelamin laki - laki yaitu 15 orang atau 45,5\% sedangkan kejadian pneumonia paling bnyak yaitu pada balita yang berjenis kelamin perempuan yaitu 16 orang atau $50 \%$. Dari hasil uji chi square didapatkan nilai $p$ value sebesar 0,714 atau $\mathrm{P}>0,05$ yang berarti secara statistik tidak ada hubungan yang signitifikan antara jenis kelamin balita dengan kejadian pneumonia pada balita di RSUD Lewoleba.

Jenis kelamin tidak berhubungan dengan pneumonia pada balita karena berdasarkan hasil penelitian di atas, kejadian pneumonia terdapat pada balita yang memiliki jenis kelamin laki - laki maupun balita yang memiliki jenis kelamin perempuan. Hasil penelitian ini sejalan dengan penelitian yang dilakukan oleh Oktaviani dan Maesaroh (2017) dalam penelitiannya yang berjudul Faktor - Faktor Yang Berhubungan Dengan Kejadian Pneumonia Pada Balita Di Puskesmas Kecamatan Teluknaga Kabupaten Tangerang. Hasil penelitianya menunjukan bahwa tidak ada hubungan antara jenis kelamin dengan kejadian pneumonia pada balita dengan hasil uji chi square didapatkan $p$ value $=0,572$ atau $\mathrm{p}>0,05$.

Menurut peneliti, jenis kelamin juga menjadi salah satu faktor resiko terhadap suatu penyakit termasuk pneumonia pada balita. Baik balita laki laki maupun perempuan pola bermain dan hubungan dengan lingkungan yang berbeda. Hal ini secara tidak langsung berhubungan dengan pneumonia pada balita oleh karena mikroorganisme pneumonia berasal dari lingkungan luar.

Hubungan antara tingkat pendidikan orang tua dengan kejadian pneumonia pada balita di RSUD Lewoleba

Berdasarkan table 2 kejadian pneumonia paling banyak pada balita yang memiliki orang dengan tingkat pendidikan rendah yaitu 23 orang dengan presentasi $71,9 \%$ sedangkan kejadian pnemoniapada balita yang memilki tingkat tingkat pendidikan yang tinggi yaitu 8 orang dengan presentasi $24,2 \%$. Dari hasil uji chi square didapatkan $p$ value sebesar 0,000 atau $\mathrm{P}$ $<0,05$ yang artinya ada hubungan antara tingkat pendidikan orang tua dengan kejadian pneumonia pada balita.

Hasil penelitian ini sejalan dengan penelitan yang dilakukan oleh Elynda dan Sulistyorini (2013). Penelitian yang dilakukan oleh Elynda dan Sulistyorini berjudul Pengaruh Kesehatan Lingkungan Rumah Terhadap Kejadian Pneumonia Pada Balita Di Wilayah Kerja Puskesmas Tambakrejo Kecamatan Simokerto Surabaya menggunakan metode penelitian analitik dengan pendekatan kasus control. Hasil penelitiannya salah satunya menguji hubungan antara pendidikan orang tua dengan kejadian 
pneumonia dengan hasil uji statistik $p$ value $=0,008$.

Tingkat pendidikan dibagi menjadi pendidikan rendah yaitu tidak sekolah, SD, SMP dan sederajat, sedangkan pendidikan tinggi yaitu SMA dan sederajat, Diploma atau perguruan tinggi (Arikunto, 2006 dalam Wawan dan Dewi, 2011). Menurut Notoatmodjo (2012) Tingkat pendidikan seseorang menentukan kemampuanya dalam menyerap dan memahami pengetahuan termasuk pengetahuan tentang kesehatan. Hal ini dapat dijadikan landasan dalam memberikan penyuluhan yang tepat. Pendidikan yang baik bagi orang tua diperlukan agar seseorang dapat lebih memahami dan tanggap terhadap masalah kesehatan seperti pneumonia pada anak balita dalam keluarga sehingga, orang tua lebih cepat tanggap dan mampu mengambil tindakan secepatnya seperti penanganan maupun pencegahan penyakit seperti pneumonia pada balita.

Menurut asumsi peneliti, pendidikan orang tua berhubungan dengan pengetahuan kesehatan pada balita. Semakin tinggi tingkat pendidikan orang tua, semakin tinggi juga pengetahuan terhadap pencegahan maupun penanganan pneumonia pada balita. Orang tua harus memiliki pendidikan yang baik sehingga dapat menerima dan menyerap pengetahuan tentang promosi kesehatan yang diberikan tenaga kesehatan baik itu tentang pneumonia maupun penyakit lain yang beresiko pada balita

Hubungan antara status gizi balita
dengan kejadian pneumonia pada
balita di RSUD Lewoleba
Berdasarlan table 2 kejadian pneumonia paling banyakpada balita yang memiliki status gizi buruk yaitu 14 orang dengan presentasi $100 \%$ kemudian balita dengan status gizi sedang yaitu 12 dengan presentasi $70,4 \%$ dan kejadian pneumonia paling rendah pada balita dengan status gizi baik yaitu 5 orang dengan presentase 14,7\%. Dari hasil uji chi square didapat $p$ value sebesar 0,000 atau $\mathrm{P}<0,05$ yang artinya ada hubungan antara status gizi dengan kejadian pneumonia pada balita di RSUD Lewoleba.

Hasil penelitian ini didukung dengan penelitian yang dilakuan oleh Ariana (2015). Penelitian yang dilakukan oleh Ariana yang berjudul Hubungan Status Gizi Dengan Kejadian Pneumonia Pada Balita Di Wilayah Kerja Puskesmas Pedan Klaten menggunakan metode penelitian case control menunjukan hubungan antara status gizi dengan kejadian pneumonia dengan hasil uji chi square nilai $\mathrm{p}=0,025, \mathrm{OR}=2,786$ dan 95\% CI $=1,125-6,899$. Sehingga dapat disimpulkan bahwa ada hubungan antara status gizi dengan kejadian pneumonia pada balita.

Menurut asumsi peneliti, status gizi menjadi indikator kesehatan yang sangat penting bagi balita. Asupan gizi yang baik akan memberikan imun tubuh yang baik terhadap berbagai penyakit termasuk pneumonia pada balita.

\section{Hubungan antara riwayat BBLR dengan kejadian pneumonia pada balita di RSUD Lewoleba}

Berdasarkan tabel 2 kejadian pneumonia pada balita yang memiliki riwayat BBLR yaitu 14 orang dengan presentase 93,3\%, sedangkan kejadian pneumonia pada balita yang tidak memiliki riwayat BBLR yaitu 17 dengan 
presentase $34,0 \%$. Dari hasil uji chi square didapatkan $p$ value $=0,000$ atau $p$ value $<0,05$ yang artinya ada hubungan antara riwayat BBLR dengan kejadian pneumonia pada balita di RSUD Lewoleba. Hasil penelitian ini sejalan dengan penelitian yang dilakukan oleh Nira (2013) dalam penelitiannya yang berjudul Risk Factors of Pneumonia Among Under Five Children in Purbalingga District, Central Java Province menggunakan jenis penelitian metode penelitian case control. Hasil penelitiannya menunjukan hubungan antara BBLR dengan kejadian pneumonia pada balita dengan hasil uji statistik $p$ value $=0,04$. Dapat disimpulkan bahwa ada hubungan antara riwayat BBLR dengan kejadian pneumonia pada balita. Menurut Round, Stradling, dan Myers (2008) pada BBLR atau bayi lahir dengan berat rendah terjadi defisiensi imun baik cellular maupun humoral imun. Hal ini dapat menyebabkan balita mudah terpapar mikroorganisme tertentu. Mikroorganisme tersebut dapat menyebabkan balita mengalami penyakit infeksi, salah satunya yaitu infeksi pernapasan seperti pneumonia.

Menurut asumsi peneliti, balita dengan riwayat BBLR memiliki sistem imun yang rendah sehingga balita menjadi rentan terhadap berbagai penyakit termasuk pneumonia pada balita. Balita dengan riwayat BBLR harus mendapat status gizi, status imunisasi yang baik. Hal ini dapat mencegah balita dengan riwayat BBLR dari berbagai infeksi penyakit termasuk pneumonia

\section{Hubungan antara status imunisasi dengan kejadian pneumonia pada balita}

Berdasarkan tabel 2 kejadian pneumonia pada balita yang memiliki status imunisasi tidak lengkap adalah 8 orang dengan presentasi $66,7 \%$ sedangkan kejadian pneumonia pada balita yang memiliki status imunisasi lengkap yaitu 23 orang dengan presentasi 43,4\%. Dari hasil uji statistic chi square didapatkan $p$ value adalah 0,145 atau $p$ value $>0,005$ yang artinya secara statistik tidak ada hubungan antara status imunisasi dengan kejadian pneumonia pada balita di RSUD Lewoleba.

Hasil penelitian ini tidak sejalan dengan penelitian yang dilakukan oleh Tambunan (2013). Penelitian yang dilakukan oleh Tambunan (2013) berjudul Faktor-Faktor Risiko Kejadian Pneumonia Pada Balita Di Wilayah Kerja Puskesmas Kedungmundu Kota Semarang Tahun 2013. Dalam penelitianya menunjukan hubungan antara status imunisasi dengan kejadian pneumonia pada balita dengan hasil uji statistik chi square diperoleh $p$ value $=$ $0,009(\mathrm{p}<0,05)$.

Menurut peneliti kebanyakan balita yang dirawat di RSUD Lewoleba sudah memiliki status imunisasi yang lengkap oleh karena fasilitas kesehatan sudah mencakup daerah - daerah terpencil.

\section{Hubungan antara keberadaan anggota keluarga perokok dengan kejadian pneumonia pada balita di RSUD Lewoleba}

Berdasarkan tabel 2 kejadian pneumonia pada balita yang memiliki anggota keluarga perokok yaitu 31 orang dengan presentasi $81,6 \%$ sedangkan 
kejadian pneumonia pada balita yang tidak memiliki anggota keluarga perokok adalah 0 dengan presentasi $0,00 \%$. Dari hasil uji statistik chi square didapat $\mathrm{P}$ value sama dengan 0,000 atau $p$ value < 0,05 yang berarti ada hubungan antara keberadaan anggota keluarga perokok dengan kejadian pneumonia pada balita di RSUD Lewoleba.

Hasil penelitian ini sejalan dengan penelitian yang dilakukan oleh Widayat (2014). Penelitian yang dilakukan oleh Widayat (2014) berjudul Faktor-Faktor Yang Berhubungan Dengan Pneumonia Pada Balita Di Wilayah Puskesmas Mojogedang II Kabupaten Karanganyar menggunakan jenis penelitian observasional dengan desain penelitian case control menunjukan bahwa ada hubungan antara keberadaan anggota keluarga yang merokok dengan kejadian pneumonia pada balita dengan hasil uji statistik $p$ value $=0,03$. Berarti ada hubungan antara keberadaan anggota keluarga perokok dengan kejadian pneumonia pada balita.

Menurut asumsi peneliti, keberadaan anggota keluarga perokok memberikan dampak penyakit pada balita. Asap rokok yang mengandung berbagai zat polutan dapat dihirup oleh balita dapat menyebabkan infeksi pernapasan seperti pneumonia. Orang tua diharapkan apabila sedang merokok tidak berdekatan dengan balita oleh karena asap rokok dapat menyebabkan pneumonia pada balita.

\section{Hubungan antara penggunaan bahan bakar masak dengan kejadian pneumonia pada balita di RSUD Lewoleba}

Berdasarkan tabel 2 kejadian pneumonia pada balita dengan penggunaan bahan bakar masak kayu bakar di rumah adalah 96,4\% sedangkan kejadian pneumonia pada balita dengan pengguanaan bahan bakar masak LPG dan minyak tanah adalah $18,9 \%$. Dari hasil uji statistik chi square didapatkan $p$ value sama dengan 0,000 atau $\mathrm{P}>0,05$ yang artinya ada hubungan antara penggunaan bahan bakar masak dengan kejadian pneumonia pada balita di RSUD Lewoleba.

Hasil penelitian ini sejalan didukung oleh penelitian yang dilakukan oleh Sugiharto dan Nurjazuli (2012). Penelitian yang Sugiharto dan Nurjazuli (2012) berjudul Analisis Faktor Risiko Kejadian Pneumonia Pada Balita Di Wilayah Kerja Puskesmas Sidorejo Kota Pagar Alam dengan menggunakan metode penelitian retrospective study dengan pendekatan case control. Hasil penelitianya menunjukan hubungan antara jenis bahan bakar masak dengan kejadian pneumonia pada balita dengan hasil uji statistik $p$ value $=0,001$. Sehingga disimpulkan bahwa ada hubungan yang signitifikan antara jenis bahan bakar masak dengan kejadian penumonia pada balita. Menurut asumsi peneliti, menggunakan bahan bakar kayu dapat dapat menyebabkan infeksi pernapasan pada balita termasuk pneumonia. Bahan bakar kayu menghasilkan asap yang banyak sehingga dapat menyebabkan pneumonia pada balita. Sebaliknya menggunakan bahan bakar LPG dan minyak tanah memiliki resiko yang rendah terhadap infeksi pernapasan termasuk pneumonia. Bahan bakar LPG dan minyak tanah lebih sedikit menghasilkan asap polusi yang menjadi penyebab infeksi pernapasan pneumonia pada balita. 


\section{Hubungan antara pengetahuan orang tua dengan kejadian pneumonia pada balita di RSUD Lewoleba}

Berdasarkan tabel 2 kejadian pneumonia pada balita yang memiliki orang tua dengan tingkat pengetahuan kurang adalah 16 dengan presentasi $94,1 \%$, pada balita yang memiliki orang tua dengan tingkat pengetahuan cukup adalah 7 dengan presentasi $31,8 \%$, pada balita yang memiliki orang tua dengan tingkat pengetahuan baik adalah 8 dengan presentasi 30,8. Hasil uji statistik chi square menunjukan nilai $p$ value sama dengan 0,000 artinya ada hubungan antara pengetahuan orang tua dengan kejadian pneumonia pada balita di RSUD Lewoleba.

Hasil penelitian ini sejalan dengan penelitian yang dilakukan oleh Rachmawati (2013). Penelitian yang dilakukan Rachmawati (2013) berjudul Faktor Risiko Yang Berhubungan Dengan Kejadian Pneumonia Pada Balita Umur 12 - 48 Bulan Di Wilayah Kerja puskesmas Mijen Kota Semarang menggunakan metode penelitian case control. Dalam penelitianya menunjukan hubungan antara pengetahuan ibu dan pengasuh dengan kejadian pneumonia pada balita dengan hasil uji statistik chi square $\mathrm{p}=0,0418(\mathrm{p}<0,5)$. Sehingga dapat disimpulkan bahwa ada hubungan antara pengetahuan ibu dan pengasuh dengan kejadian pneumonia pada balita.

Menurut asumsi peneliti, berdasarkan hasil penelitian dan teori tentang pengetahuan di atas, tingkat pengetahuan orang tua berperan penting pada kejadian pneumonia pada balita. Pengetahuan orang tua tentang yang baik akan berdampak pada peran orang tua dalam melakukan pencegahan terhadap infeksi pernafasan baik itu pneumonia maupun bukan pneumonia.

\section{KESIMPULAN DAN SARAN}

Kesimpulan:

Hasil penelitian ini adalah umur, jenis kelamin dan status imunisasi balita tidak memiliki hubungan dengan kejadian pneumonia pada balita yang dirawat di RSUD Lewoleba. Tingkat pendidikan orang tua, status gizi balita, riwayat BBLR balita, keberadaan anggota keluarga perokok, penggunaan bahan bakar masak, dan pengetahuan orang tua memiliki hubungan dengan kejadian pneumonia pada balita di RSUD Lewoleba.

Saran:

Dikarenakan pengetahuan orang tua tentang pneumonia pada balita kurang, maka disarankan kepada perawat RSUD Lewoleba agar memberikan penyuluhan kesehatan tentang pneumonia pada balita kepada orang tua. Agar penyuluhan pneumonia direncanakan dengan baik secara rutin dan berlanjut dapat membentuk grup atau individu dalam proses penyuluhannya. Hal ini bertujuan meningkatkan pengetahuan orang tua yang masih kurang serta dapat mencegah maupun melakukan pertolongan pertama pada balita dengan pneumonia.

\section{DAFTAR RUJUKAN}

Wawan, A, dan Dewi. M (2011). Teori dan Pengukuran Pengetahuan, Sikap, dan Perilaku Manusia. Yogyakarta: Nuha Medika

Anggraeny, O., \& Ariestiningsih, A. D. (2017). Gizi Prakonsepsi, Kehamilan, dan Menyusui. Malang:UB Press 
Ariana, S. (2015). Hubungan Status Gizi dengan Kejadian Pneumonia pada Balita di Wilayah Kerja Puskesmas Pedan Klaten. Journal FKM Universitas Muhamadiyah Surakarta.

Bappenas. (2015). Seri Analisis Pembangunan Wilayah Propinsi Nusa Tenggara Timur 2015.

Chamidah, A. N. (2009). Pentingnya Stimulasi Dini bagi Tumbuh Kembang Otak Anak.Journal UNY.

Dinas Kesehatan Provinsi NTT. (2015). Profil Kesehatan Nusa Tenggara Timur Tahun 2015, 48-49. Profil Kesehatan NTT

Elynda, S. R., \& Sulistyorini, L. (2014). Pengaruh Kesehatan Lingkungan Rumah terhadap Kejadian Pneumonia pada Balita di Wilayah Kerja Tambakrejo Kecamatan Simokerto Surabaya. Jurnal Kesehatan Lingkungan

Fleisher, G. R., \& Stephen, L. (2010). Textbook Of Pediatric Emergency Medicine. Philadelphia: Lippincott Williams \& Wilkins

Hadiana, S. Y. (2013). Hubungan Status Gizi Terhadap Terjadinya Infeksi Salurann Pernapasan Akut (ISPA) Pada Balita DI Puskesmas Pajang Surakarta.Jurnal Fakultas Kedokteran Universitas Muhammadiyah Surakarta.

Hidayat, S., Yunus, F., \& Susanto, A. D. (2012). Pengaruh Polusi Udara dalam Ruangan terhadap Paru. Continuing Medical Education.

Hockenberry, M. J., \& Wilson, D. (2015). Wong's Nursing Care of Infants and Children. St.Louis, Missouri: Elsevier.
Hockenberry, M. J., \& Wilson, D. (2016). Wong's Nursing Care of Infants and Children.St.Louis, Missouri: Elsevier.

Huether, S. E., \& McCance, K. L.(2017). Understanding Pathophysiology. Missouri: Elsevier.

Kaunang, C. T., Runtunuwu, A. L., \& Mahawani, A. M. (2016). Gambaran Karakteristik

Pneumonia pada Anak yang Dirawat di Ruang Perawatan Intensif Anak RSUP Prof. Dr.R. D. Kandou Manado. Jurnal e-Clinic.

Kemenkes RI. (2010). Pneumonia Balita. Buletin Jendela Epiemiologi. Kemenkes RI. (2011). Peraturan Menteri Kesehatan Republik Indonesia Nomor 1077/Menkes/Per/V/2011 Tentang Pedoman Penyehatan Udara dalam Ruang Rumah. Journal PMK

Kemenkes RI. (2014). Pedoman Pelaksana Stimulasi, Deteksi dan Intervensi Dini Tumbuh kembang Anak di Tingkat Pelayanan Kesehatan Dasar.Buku Deteksi Dini Tumbuh kembang Balita.

Kemenkes RI. (2013). Riset Kesehatan Dasar. Badan Penelitian dan Pengembangan Kesehatan Kementerian Kesehatan RI.

Kemenkes RI. (2015). Situasi Anak Balita di Indonesia.Infodatin Anak Balita.

Kliegman, Staton, St Geme, \& Schor. (2016). Nelson Textbook Pediatrics. Philadelphia: Elsevier.

Nelson, M. R. (2010). Pediatrics: Rehabilitation Medicine Quick Reference. New York: Demos Medical Publishing. 
Nira, N. K. (2013). Risk Factor of Pneumonia Among Under Five Children in Purbalingga District, Central Java Province.Topical Medicine Journal.

Notoatmodjo, S. (2012). Promosi Kesehatan dan Perilaku Kesehatan. Jakarta: Rineka Cipta.

Oktaviani, I., \& Maesaroh, S. (2017). Faktor Faktor Yang Berhubungan Dengan Kejadian

Pneumonia Pada Balita di Puskesmas Kecamatan Teluknaga Kabupaten Tangerang. Jurnal Komunikasi Kesehatan.

Rachmawati, D. A. (2013). Faktor Risiko yang Berhubungan dengan Kejadian Pneumonia pada Balita Umur 12 - 48 Bulan di Wilayah Kerja Puskesmas Mijen Kota Semarang. Jurnal Kesehatan Masyarakat.

Round, J., Stradling, L., \& Myers, A. (2008). Paediatrics Clinical Cases Uncovered. Oxford: WILLEY-BLACKWELL.

Sugihartono, \& Nurjazuli. (2012). Analisis Faktor Risiko Kejadian Pneumonia pada Balita di Wilayah Kerja Puskesmas Sidorejo Kota Pagar Alam. Jurnal Kesehatan Lingkungan Indonesia, 84-85.

Susilo, W. H. (2013). Prinsip - Prinsip Biostatistik dan Aplikasi SPSS. Jakarta: IN MEDIA.

Widayat, A. (2014). Faktor-Faktor yang Berhubungan dengan Pneumonia pada Balita di Wilayah Puskesmas Mojogedang di Kabupaten Karanganyar. Jurnal Publikasi Ilmiah 